\title{
KADIN İŞGÜCÜNE YÖNELİK ILO SÖZLEŞMELERİ VE UYGULANIRLIĞI: MEVZUATLAR AÇISINDAN TÜRKIYYE- ITALYA KARŞILAŞTIRMASI
}

\author{
Demet TÜZÜNKAN ${ }^{1}$
}

\begin{abstract}
Özet:
Kadınlar işgücünde gençler, engelliler gibi dezavantajlı gruplar içinde yer almaktadırlar. Uluslararası Çalışma Örgütü'nün kadınlara yönelik ayrımcılığı önleyici, kadın istihdamını teşvik edici, işgücündeki kadınların gebelik ve annelik haklarını koruyucu yönleriyle öne çıkan 4 adet sözleşmesi bulunmaktadır. Bu sözleşmeler; 100 sayılı Eşit Ücret Sözleşmesi, 111 sayılı Ayırımcılık (İş ve Meslek) Sözleşmesi, 156 sayılı Aile Sorumlulukları Olan Kadın ve Erkek İsçilere Eşit Davranılması ve Eşit Fırsatlar Tanınması Hakkında Sözleşme ve 183 sayılı Kadının Doğum ve Doğum Sonrası Çalışması Hakkında Sözleşme'dir. Bu sözleşmelerin bazıları hem Türkiye hem İtalya tarafından kabul edilmemiş olup her iki ülkenin de kanunları bu sözleşmelerin içeriklerine yönelik farklılıklar da içermektedir. Bu çalışma ILO sözleşmelerinin gereklerine uygun olup olmaması açısından Türkiye ve İtalya mevzuatlarının karşılaştırmasını içermektedir.
\end{abstract}

Anahtar Kelimeler: Kadın İşgücü, ILO, Ayrımcılık, Analık, Gebelik

JEL kodu: J71, J8, J1, K31

\section{ILO CONVENTIONS FOR WOMEN LABOUR FORCE AND THEIR APPLICABILITY: TURKEY AND ITALY COMPARISION WITH THE VIEWPOINT OF LEGISLATIONS}

\begin{abstract}
:
In labour force, women take part in disadvantaged groups such as people with disabilities or youngs. There are four conventions of ILO that prevent discrimination against women, promote women employments and protects women's maternity rights. These conventions are; C100 Equal Remuneration Convention, C111 Discrimination (Employment and Occupation) Convention, C156 Workers With Family Responsibilities Convention and C183 Maternity Protection Convention. Some of these conventions has not been accepted by both Turkey and Italy yet. So, laws include differences for the content of these conventions. This study is a comperative study between Turkish and Italian legislations with respect to ILO requirements.
\end{abstract}

Keywords: Women Labour, ILO, Discrimination, Maternity

\footnotetext{
${ }^{1}$ Yrd. Doç. Dr., Beykent Üniversitesi, demettuzunkan@beykent.edu.tr
} 


\section{Giriș}

Sanayileşme ile değişen üretim ve istihdam yapısına bağlı olarak kadınlar çalışma hayatında daha fazla yer almaya başlamışlardır. Ancak, kanun önünde tüm kadın ve erkekler eşit haklara sahip olsalar da iş yaşamında kadınların erkekler ile eşit haklara sahip olmadıkları ve erkeklere kıyasla eğitim, ücret, istihdam edilme ve işgücüne katılma hususlarında daha düşük seviyelerde kaldıkları ulusal ve uluslararası istatistiklerde görülmektedir. İş ve aile yaşamı dengesi kurmalarındaki sorumlulukları açısından kadınların çalışma koşulları erkeklere kıyasla daha zor olmaktadır. Bu konuda ILO, iş hayatında kadın-erkek eşitliği olması gerekliliğin altını çizmekte ve kadınların aile sorumlulukları sebebiyle iş hayatında mağdur edilmemeleri için çeşitli sözleşmelerle hükümlerde bulunmaktadır. Sözleşmeleri imzalayan ülkeler sözleşmelerin içeriklerine istinaden mevzuatlarını düzenlemekle mükelleftirler.

Çalışmada Türkiye ve İtalya'nın bu sözleșmelere yönelik yasal yapılarının içerikleri ele alınmaktadır. Öncelikle her iki ülkenin kadın istihdamına ait rakamlar ve istatistikler verilmekte ve elde edilen rakamların mevzuatlara uygunlukları tartışılmaktadır.

\section{Kadın İşgücü}

Kadın işgücüne ait verilerden önce Türkiye ve İtalya'nın kadın nüfus yoğunluğuna ait bilgiler aşağıdaki tabloda verilmektedir.

Tablo 1: Türkiye ve İtalya Toplam Nüfus ve Kadın Nüfusu (2008-2012)

\begin{tabular}{|c|c|c|c|c|c|c|}
\hline & \multicolumn{2}{|c|}{ Toplam Nüfus } & \multicolumn{2}{c|}{ Kadın Nüfusu } & \multicolumn{2}{c|}{ Kadın Nüfusu \% } \\
\hline Yıllar & İtalya & Türkiye & İtalya & Türkiye & İtalya & Türkiye \\
\hline 2008 & 59.832 .180 & 71.051 .680 & 30.781 .090 & 35.419 .980 & $51,45 \%$ & $49,85 \%$ \\
\hline 2009 & 60.192 .700 & 72.039 .210 & 30.972 .780 & 35.857 .390 & $51,46 \%$ & $49,77 \%$ \\
\hline 2010 & 60.483 .380 & 73.142 .150 & 31.133 .050 & 36.389 .320 & $51,47 \%$ & $49,75 \%$ \\
\hline 2011 & 60.626 .440 & 74.223 .630 & 31.213 .170 & 36.935 .560 & $51,48 \%$ & $49,76 \%$ \\
\hline 2012 & 60.916 .200 & 75.175 .820 & 31.361 .390 & 37.431 .260 & $51,48 \%$ & $49,79 \%$ \\
\hline
\end{tabular}

Kaynak: OECD.Stat, Population Statistics

Yukarıdaki tabloya göre İtalya'da ve Türkiye'de kadın nüfusu erkek nüfusuna eşit yakınlıkta gözükmektedir. İtalya'da tüm nüfus içinde kadın nüfusunun payı OECD 2012 yılı verilerine göre \%51,48 iken Türkiye'de bu oran \%49,79'dur.

Tablo 2: Türkiye Toplam ve Kadın İşgücü Verileri (1000 kişi) (2009-2013)

\begin{tabular}{|c|c|c|c|c|c|c|}
\hline & & $\mathbf{2 0 0 9}$ & $\mathbf{2 0 1 0}$ & $\mathbf{2 0 1 1}$ & $\mathbf{2 0 1 2}$ & $\mathbf{2 0 1 3}$ \\
\hline İşücü & Tr. & 23.710 & 24.594 & 25.594 & 26.141 & 27.046 \\
\hline & Kadın & 6.851 & 7.383 & 7.859 & 8.192 & 8.674 \\
\hline İstihdam & $\mathbf{T r}$. & 20.615 & 21.858 & 23.266 & 23.937 & 24.601 \\
\hline & Kadın & 5.871 & 6.425 & 6.973 & 7.309 & 7.641 \\
\hline İșsiz & Tr. & 3.095 & 2.737 & 2.328 & 2.204 & 2.445 \\
\hline & Kadın & 979 & 959 & 885 & 883 & 1.033 \\
\hline İKO* & Tr. & $45,70 \%$ & $46,50 \%$ & $47,40 \%$ & $47,60 \%$ & $48,30 \%$ \\
\hline & Kadın & $26 \%$ & $27,60 \%$ & $28,80 \%$ & $29,50 \%$ & $30,80 \%$ \\
\hline İO & Tr. & $13,10 \%$ & $11,10 \%$ & $9,10 \%$ & $8,40 \%$ & $9 \%$ \\
\hline
\end{tabular}




\begin{tabular}{|c|c|c|c|c|c|c|} 
& Kadın & $14,30 \%$ & $13 \%$ & $11,30 \%$ & $10,80 \%$ & $11,90 \%$ \\
\hline ISO* & Tr. & $39,80 \%$ & $41,30 \%$ & $43,10 \%$ & $43,60 \%$ & $43,90 \%$ \\
\hline & Kadın & $22,30 \%$ & $24 \%$ & $25,60 \%$ & $26,30 \%$ & $27,10 \%$ \\
\hline
\end{tabular}

Kaynak: TÜİK, Kurumsal olmayan nüfusun işgücü durumu * İKO:İşgücüne Katılım Oranı, İO:İşsizlik Oranı, İSO:İstihdam Oranı

Tablo 2'de görüldüğü üzere 2009-2013 yılları arasında kadın işgücü katılım ve istihdam rakamları ile oranları artmasına rağmen Türkiye genelinde erkek işgücü ve istihdam yoğunluğu dikkate çarpmaktadır. Kadınlar istihdamın yalnızca yaklaşı 1/4'ünü oluşturmaktadırlar. Özellikle 2013 yılına kadar düşmekte olan işsiz kişi sayısının ve işsizlik oranının 2013 yılında arttığı görülmektedir. Kadınlarda ise 2012 yılında \%10,80 olan işsizlik oranı \%11,90’a yükselerek son 4 yılın en yüksek işsizlik oranına ulaşmıştır.

Tablo 3: İtalya Toplam ve Kadın İşgücü Verileri (1000 kişi) (2009-2013)

\begin{tabular}{|c|c|c|c|c|c|c|}
\hline & & 2009 & 2010 & 2011 & 2012 & 2013 \\
\hline \multirow[b]{2}{*}{ İşgücü } & İt. & 24.969 & 24.974 & 25.075 & 25.642 & 25.532 \\
\hline & Kadın & 10.180 & 10.227 & 10.342 & 10.732 & 10.741 \\
\hline \multirow[b]{2}{*}{ İstihdam } & It. & 23.025 & 22.872 & 22.967 & 22.898 & 22.420 \\
\hline & Kadın & 9.235 & 9.238 & 9.348 & 9.458 & 9.330 \\
\hline \multirow[b]{2}{*}{ İşsiz } & İt. & 1.944 & 2.102 & 2.107 & 2.743 & 3.112 \\
\hline & Kadın & 944 & 988 & 993 & 1.274 & 1.411 \\
\hline \multirow[b]{2}{*}{ ÍKO* } & İt. & $63,10 \%$ & $62,90 \%$ & $63,90 \%$ & $66,30 \%$ & $64,60 \%$ \\
\hline & Kadın & $51 \%$ & $51,30 \%$ & $52,40 \%$ & $55,10 \%$ & $54,10 \%$ \\
\hline \multirow[b]{2}{*}{ İO* } & İt. & $7,90 \%$ & $8,50 \%$ & $8,50 \%$ & $10,80 \%$ & $12,30 \%$ \\
\hline & Kadın & $9,30 \%$ & $9,70 \%$ & $9,60 \%$ & $11,90 \%$ & $13,10 \%$ \\
\hline \multirow[b]{2}{*}{ İSO* } & İt. & $57,50 \%$ & $56,90 \%$ & $57,90 \%$ & $58,50 \%$ & $56,10 \%$ \\
\hline & Kadın & $46,60 \%$ & $46,40 \%$ & $47,40 \%$ & $48,50 \%$ & $47,00 \%$ \\
\hline
\end{tabular}

Kaynak: OECD.Stat, Population and Labour Force

* IKO:İşücüne Katılım Oranı, İO:İşsizlik Oranı, İSO:İstihdam Oranı

OECD istatistiklerinden ele edilen veriler 1şığında İtalya'da 2013 yılında toplam istihdam ve kadın istihdam oranlarında düşüş yaşanmıştır. Bununla beraber kadın işsizlik rakamında ve oranında artış görülmektedir.

Türkiye ve İtalya genel değerlendirmesi yapıldığında, İtalya'da kadınların işgücüne kayılma oranlarının Türkiye'nin neredeyse 2 katı olduğu ortaya çıkmaktadır. Kadınlar yoğun bir şekilde işgücüne katılmaktadır. 15-64 yaş arası kadınların yarıdan fazlası \%54,10 oranıyla işgücüne katılmaktayken aynı oran Türkiye'de \%30,80'dir. Dolayısıyla Türkiye'de çalışma çağındaki kadın nüfusunda her 10 kişiden ortalama 3 tanesi iş hayatında rol oynamakta veya oynamayı istemektedir. Zira işgücüne katılım oranı hesaplanırken işsizler de bu orana dahil edilmektedir.

Benzer şekilde istihdam edilme oranlarında da İtalyan kadınlarının üstünlüğü görülmektedir. İtalya'da kadınların \%47'si istihdam edilirken bu oran Türkiye'de \%27,10'dur. İşsizlik oranlarına bakıldığında ise Türkiye'de kadınların işsizlik oranı \%11,90 iken İtalya'da kadın işsizlik oranı \%13,10'dur. İşgücüne katılım oranının düşük olması sebebiyle işsizlik oranının da düşük çıkması olağandır. Bir yerde işgücüne katılım oranı ne kadar yüksekse iş arayan 
kişilerin fazla olması da olasıdır. Bu durum işsizlik oranının ve işsiz sayısının fazla çıkmasına sebep olabilmektedir.

Tablo 4: Türkiye ve İtalya Kadınların Eğitim Durumları (\%)

\begin{tabular}{|c|c|c|c|c|}
\hline & & Ilkokul & Orta+Lise & Üniversite \\
\hline \multirow{3}{*}{2009} & TR & $63,40 \%$ & $21,30 \%$ & $15,30 \%$ \\
\cline { 2 - 5 } & IT & $37,40 \%$ & $45,80 \%$ & $16,80 \%$ \\
\hline \multirow{3}{*}{2010} & TR & $63,80 \%$ & $20,40 \%$ & $15,80 \%$ \\
\cline { 2 - 5 } & IT & $36,50 \%$ & $46,50 \%$ & $17 \%$ \\
\hline \multirow{3}{*}{2011} & TR & $63,20 \%$ & $20 \%$ & $16,70 \%$ \\
\hline \multirow{2}{*}{2012} & IT & $36 \%$ & $46,70 \%$ & $17,30 \%$ \\
\cline { 2 - 5 } & TR & $61,50 \%$ & $20,20 \%$ & $18,30 \%$ \\
\hline \multirow{2}{*}{$\mathbf{2 0 1 3}$} & IT & $35,40 \%$ & $46,60 \%$ & $17,90 \%$ \\
\cline { 2 - 5 } & TR & $60,50 \%$ & $20,40 \%$ & $19 \%$ \\
\hline
\end{tabular}

Kaynak: OECD, Innovation Indicators

Tablo 4'de görüldüğü üzere işgücündeki kadınların aldıkları eğitim hususunda İtalya ve Türkiye arasında farklılıklar bulunmaktadır. Öncelikle, Türkiye'de işgücündeki kadınların yarıdan çoğu ilkokul eğitim düzeyindedir. Bunu, orta-lise eğitim düzeyi ve en son üniversite veya yüksekokul eğitim düzeyi izlemektedir. İtalya'da ise orta-lise eğitim düzeyine sahip kadın sayısı önde gelmektedir. Her iki ülkede de üniversite ve yüksekokul eğitim düzeyinin son 5 yilda artmakta, ilkokul eğitim düzeyinin ise azalmakta olduğu görülmektedir.

Tablo 5: Kadın ve Erkek Çalışanlara Yönelik Saatlik Medyan Ücret Karşılaştırması

\begin{tabular}{|c|c|c|c|l|}
\hline & \multicolumn{2}{|c|}{ Kadın } & \multicolumn{2}{c|}{ Erkek } \\
\hline & $\mathbf{2 0 0 6}$ & $\mathbf{2 0 1 0}$ & $\mathbf{2 0 0 6}$ & $\mathbf{2 0 1 0}$ \\
\hline AB 27 Ülke ortalaması & $10,47 \mathrm{EUR}$ & $11,03 \mathrm{EUR}$ & $12,23 \mathrm{EUR}$ & $12,83 \mathrm{EUR}$ \\
\hline Türkiye & $1,69 \mathrm{EUR}$ & $2,10 \mathrm{EUR}$ & 1,74 EUR & $2,14 \mathrm{EUR}$ \\
\hline İtalya & $10,52 \mathrm{EUR}$ & $11,46 \mathrm{EUR}$ & $11,17 \mathrm{EUR}$ & $12,11 \mathrm{EUR}$ \\
\hline
\end{tabular}

Kaynak:Eurostat, Median Hourly Earnings

Tablo 5'de yer alan ücret karşılaştırmasında, Eurostat'dan derlenen veriler Türkiye'de kadınlara verilen saatlik medyan ücretlerin hem AB 27 ülke ortalamasının, hem de İtalya'nın çok gerisinde olduğunu göstermektedir. İtalya'da ise ücretler AB 27 ülke ortalamasının az da olsa üstündedir. Ancak erkek ücretleri ile karşılaştıııldığında, kadınların erkeklerden az kazandıkları görülmektedir.

\section{Kadın İşgücünü Korumaya ve Geliştirmeye Yönelik ILO Sözleșmeleri}

Uluslararası Çalışma Örgütü, ayrımcılığı önlemeye, kadın işgücünü korumaya ve geliştirmeye yönelik insana yakışır iş kapsamında 4 adet sözleşme önermektedir. Bu sözleşmeler, 100, 111, 156 ve 183 sayılı sözleşmelerdir. 100 sayılı sözleşme, eşit ücret ödemelerine yönelik sözleşme olup kadın ve erkeklerin aynı iş için farklı ücretler almalarını engelleyici ve ücretleri adilce 
düzenlemeyi içeren maddeler bulundurmaktadır. 111 sayılı sözleşme, iş ve meslek seçmede, işe yerleşmede, işten ayrılmada kişiler arası ayrımcılık kavramına değinmekte olup cinsiyetler arası ayrımcılık yapılmasına karşı maddeler içermektedir. 156 sayılı sözleşme, aile sorumlulukları olan kadın ve erkeklere eşit davranılması ve eşit firsatlar tanınmasına yönelik hususlar içermektedir. Kadınların doğum ve doğum sonrası çalışmalarına yönelik maddeleri düzenleyen ve kadınların analık ve gebelik haklarını koruyan sözleşme olan 183 sayılı sözleşme ise cinsiyet ayrımcılığı hususunda UÇÖ’nün öne sürdüğü bir diğer sözleşmedir.

\section{1. $\quad 100$ sayılı Eşit Ücret Sözleşmesi (1951)}

Sözleşmenin 1. maddesinde açıkça yazıldığı üzere, "eşit değerde iş için erkek ve kadın işçiler arasında ücret eşitliği" deyimi, cinsiyet esasına dayanan bir ayırım gözetmeksizin tespit edilmiş bulunan ücret hadlerini ifade etmektedir. Ücretler temel ücret, primler, yan ödemeler, ikramiyeler gibi diğer ödemeleri de içerir. UÇÖ’nün 100 sayılı sözleşmesi, ücretlerde hiçbir gruba karşı ayrımcılığın yapılmaması gerektiğini ifade etmektedir. Bu ayrımcılık, sadece cinsiyete değil, ırk, renk, din, dil gibi diğer özellikler için de geçerlidir. Ayrıca sözleşmenin 3. maddesinde ücret eşitliğinin sağlanması için işlerin objektif olarak değerlendirilmesi gerektiğinin altı çizilmektedir.

\section{2. $\quad 111$ sayılı Ayırımcılık (İș ve Meslek) Sözleșmesi (1958)}

Sözleşmeye göre 1rk, renk, cinsiyet, din, siyasal inanç gibi özellikler bakımından yapılan iş ve ya meslek edinmede eşitliği yok edici etkisi olan her türlü ayrımcılık yasaklanmıştır (ILO, Convention 111). Sözleşmenin 2. ve 3. maddesi, sözleşmeyi kabul eden ülkelerin eşitliği geliştirmeyi hedefleyen ulusal bir politika tespit etmesine ve işçi ve işveren kuruluşlarını bu politikaların takibi için işbirliğine teşvik etmesine hükmetmektedir.

\section{3. $\quad 156$ sayılı Aile Sorumlulukları Olan Kadın ve Erkek İşçilere Eşit Davranılması ve Eşit Fırsatlar Tanınması Hakkında Sözleşme (1981)}

156 sayılı sözleșmeyi kabul eden ülkelerin aile sorumlulukları olan çalıșanların cinsiyetler arası ayrımcı uygulamalara maruz kalmaksızın çalışma hayatına katılımını sağlamak ve aile sorumlulukları ile çalışma hayatını bağdaştırabilmeleri amacıyla ulusal politikalar izlemeleri gereğini düzenlemiştir. Sözleşme çalışan kadınların herhangi bir ayırımcılık söz konusu olmadan, çalışma hayatında aile sorumlulukları ile arasında bir tercih yaratmaksızın yer alabilmelerini düzenlemektedir. İş ortamında yeterli sayıda çocuk bakım ünitelerinin yer alması, aile sorumluluklarına ilişkin sosyal destek hizmetlerinin sağlanması, doğum sonrasında babaya da çocuğun bakımı için izin verilmesi, aile sorumlulukları sebebiyle işten ayrılanlara tekrar işe dönebilme imkanının getirilmesi gibi düzenlemelerle kadını ve aileyi koruyucu ve istihdam güvencesi getirici hükümler içermektedir (ILO, Convention 156).

\subsection{3 sayılı Kadının Doğum ve Doğum Sonrası Çalışması Hakkında Sözleșme (2000)}

183 sayılı Kadının Doğum ve Doğum Sonrası Çalışması Hakkında Sözleşme (2000), analık halinin korunmasına yönelik en çok revize edilmiş sözleşmedir (ILO,2012). Sözleşmede verilen hükümler şu şekildedir (ILO, Convention 183);

- Kadınlara doğum nedeniyle verilecek izin 14 haftadan az olamaz ve özellikle doğum sonrası verilecek izin ulusal mevzuat çerçevesinde belirlenecek olsa da bu izin de 6 haftadan az olamayacaktır, 
- Kadının hamilelik nedeniyle ayrıldığı işine tekrar aynı pozisyonda dönebilmesi imkanı bulunmaktadir,

- Kadın çalıșma sırasında günde bir ya da daha fazla emzirme izni alabilecektir,

- Doğum sonrasında kadına hastalık yardımı yapılacak ve kadınların hamilelik ve doğum nedeniyle işten çıkarılmaları yasaklanacaktır.

183 sayılı Sözleşme, hangi meslekte ne tür bir iş yapıyorlarsa yapsınlar tüm kadınları kapsamaktadır. Bu sözleşme, ekonomik güvenlik, iş güvencesi, anne ve bebek sağlığı ile toplumsal cinsiyet eşitliği konularında kadına pozitif ayrımcılık sunan bir içeriktedir.

\section{ILO Sözleşmeleri Açısından Türkiye-İtalya Mevzuat Karşılaştırması}

\section{1. $\quad 100$ Sayılı Sözleșme}

Italya: 100 sayılı sözleşme İtalyan hükümeti tarafından kabul etmiştir ve anayasanın 3. maddesine göre herkes kanun önünde eşit muamele görme hakkına sahiptir. Irk, din, dil, sosyal ve kişisel şartlar gibi hiçbir konuda hiç kimseye farklı bir şekilde davranılamaz. Ayrıca aynı anayasanın Ekonomik İlişkiler başlığı altında yer alan 37. maddesi, kadınların eşit değerde iş için ücret eşitliği altında çalışmaları hususuna değinmektedir (Senato Della Repubblica). Zira Avrupa Birliği'ne üye olan tüm ülkeler için ortak şart koşan Avrupa Hukuku'nun 142/A maddesi de eşit değerde işler için eşit ödemeler yapılması konusunda tüm üye ülkeler bağlayıcı bir direktif içindedir (Council of the European Union, 2010). İtalya'da kadın ve erkekler arasında eşit fırsatlara ilişkin 198/2006 sayılı kanun sonradan 25 Ocak 2010 tarihli 5 sayılı kararname olarak değiştirilmiş ve bu madde Avrupa Birliği yasalarına uyumlu hali ile cinsiyetler arası ayrımcılığı tamamen engelleyen, kadınların iş hayatına eşit olarak katılımını destekleyen bir yasa haline gelmiştir (Burri, 2014). Ancak ücretlerin eşit olarak verilip verilmediğini tespit etmek kolay değildir. Çünkü bahşişler, primler gibi ek ödemeler iş veren tarafından verilmekte ve baz ücretin üstünde ne kadar para kazanıldığını tespit etmek mümkün olmamaktadır (De Simone and Rivara, 2006).

Türkiye: Bu sözleşmeyi onaylayan ${ }^{2}$ Türkiye'nin 4857 sayılı iş kanununda da ücret eşitliğine yönelik bir madde bulunmaktadır. 5 numaralı maddede, eşit davranma ilkesine yönelik şu hüküm geçmektedir;

\section{Aynı veya eşit değerde bir iş için cinsiyet nedeniyle daha düşük ücret kararlaştırılamaz. Isşçinin cinsiyeti nedeniyle özel koruyucu hükümlerin uygulanması, daha düşük bir ücretin uygulanmasını haklı kılmaz.}

Bu madde ile kadın ve erkek arasında ayrımcılık yapılmaması gereği kanun ile koruma altına alınmıştır. 4857 sayılı kanunda yer alan bu maddenin yanı sıra 25 Mayıs 2010 tarihli Resmi Gazete'de yayımlanan Başbakanlık genelgesine göre kadın istihdamının arttırılması ve firsat eşitliğinin sağlanması konusunda hem istihdam hem ücretler açısından cinsiyet ayrımcılığını önleyici tedbirler alınması gündeme getirilmiştir.

4857 sayılı İş Kanunu'nun 32. maddesi ücretlerle ilgili düzenlemeleri içermektedir. Bu maddeye göre, Türkiye'de ücretin ödeme şekli olarak Türk parası ile ve banka kanalıyla, en geç 1 ay içinde de ödenmesi gerekmektedir. Benzer şekilde 6098 sayılı Borçlar Kanunu'nun 407. Maddesi, ücretin banka kanalı aracılığı ile ödenmesi hükmünü içermektedir. Hem İş Kanunu'nun hem Borçlar Kanunu'nun bu uygulaması ücretin ödenme şekli olarak da ayrımcılığı önlemekte olup cinsiyetler arası ücret ayrımcılığına karşı işçileri koruma görevi taşımaktadır.

\footnotetext{
${ }^{2}$ Kanun Tarih ve Sayısı: 13 Aralık 1966 / 810, Resmi Gazete Yayım Tarihi ve Sayısı: 22 Aralık 1966 / 12484
} 
Ücretin ödenme şekline ilişkin ÇSGB'nın ücret, prim, ikramiye ve bu nitelikteki her türlü istihkakın bankalar aracılığgyla ödenmesine dair yönetmeliği bulunmaktadır. Bu yönetmeliğin 10. maddesi, İş Kanununa tabi olarak çalışan işçilerin iş yerlerinde işçi sayısının en az on olması halinde ücretin banka kanalıyla ödeneceği hükmü geçmekte olup, on kişiden az işçinin çalıştığı yerler bu maddeden faydalanamamaktadırlar.

\section{2. $\quad 111$ Sayılı Sözleşme}

İtalya: 111 sayılı bu sözleşmeyi İtalya kabul etmiştir. Her türlü ayrımcılığa karşı olmak temel insan haklarından biridir. Çalışma hayatında da kişiler işlerini özgürce, hiçbir baskı altında olmadan seçmeli ve kendilerini istedikleri yönde geliştirebilmelidirler (ILO Manual, 2012). Avrupa Birliği müktesebatında hem Eşit Fırsatlar adı altında hem de Ayrımcılık Karşıtlığı hakkında başlıklar bulunmaktadır. Bu başlıklar içeriğinde hem tüm insanlar arasında hem de kadın ve erkekler arasında ayrımcı davranışları engelleyici hususlar barındırmaktadırlar ve üye ülkelere bir rehber niteliğindedirler (Summaries of EU Legislation). Önceki sözleșmede de değinildiği üzere İtalya anayasanın 3. maddesi herkesin kanun önünde eşit muamele görme hakkına sahip olduğunu, 1rk, din, dil, sosyal ve kişisel şartlar gibi hiçbir konuda hiç kimseye farklı bir şekilde davranılamayacağını belirtmektedir (Senato Della Repubblica). İtalya anayasası iş ve meslek ayrımcılığı bakımından kabul ettiği bu sözleşmenin gereklerine uygun olarak düzenlenmiştir. Bu durum tüm çalışanları kapsamaktadır.

Türkiye: Türkiye'nin onayladığı ${ }^{3}$ bu sözleşmeye göre her türlü ayrımcılığa karşı olmak temel insan haklarından biridir. İş kanunundan evvel Anayasa'nın 10. maddesi herkesi kanun önünde eşit görmekte, kadın ve erkeklerin eşit haklara sahip olduğunu belirtmektedir. Çalışma hayatında da kişiler işlerini özgürce, hiçbir baskı altında olmadan seçmeli ve kendilerini istedikleri yönde geliştirebilmelidirler (ILO, 2012, p.133). 4857 sayılı kanunun 5. maddesinin 3. fikrasında hem iș hayatına atılmada hem de iș şartlarının olușturulmasında kadın erkek eşitliğini sağlayacak düzenlemeler bulunmaktadır. 4857 sayılı kanunun 5. maddesi iş hayatında kadın erkek eşitliğini UÇÖ şartlarına da uyumlu olacak bir konumda ele alınmıştır. $\mathrm{Bu}$ maddeye göre kadınlara farklı işlem yapılmaması gerektiğine dair hüküm aşağıdaki şekilde açıça belirtilmektedir;

İşveren, biyolojik veya işin niteliğine ilişkin sebepler zorunlu kılmadıkça, bir işçiye, iş sözleşmesinin yapılmasında, şartlarının oluşturulmasında, uygulanmasında ve sona ermesinde, cinsiyet veya gebelik nedeniyle doğrudan veya dolayl farklı işlem yapamaz.

Doğrudan cinsiyet ayrımcılı̆̆ oranla daha farklı işleme tabi tutulması olarak tanımlanabilir. Bir iş için sadece kadınların ya da erkeklerin aranıyor olması veya işverenin başvuranlar arasında sadece kadınları ya da sadece erkekleri (haklı bir gerekçe olmaksızın) işe uygun bulması doğrudan ayrımcılığın örneklerini oluşturmaktadır. Buna benzer olarak, bir işyerinde sadece belli bir cinsiyete yönelik ikramiye ödenmesi de doğrudan cinsiyet ayrımcılığına örnektir (Demiral, 2005). Ancak bir işin yerine getirilmesi belli bir cinsiyete kanunen yasaklanmış ise, bu durumda da 5. maddeye aykırılıktan söz edilemeyecektir. Örneğin 4857 sayılı iş kanununun 72 . maddesine göre kadınların yeraltı ve sualtında çalıştırılmaları yasaklanmıştır. Sonuç olarak böyle bir durumda cinsiyet ayrımcılığından bahsedilmemektedir.

\section{3. $\quad 156$ sayılı sözleşme}

İtalya: İtalya, bu sözleşmeyi kabul etmemiştir. Ancak İtalyan anayasasının 37. maddesi, kadının iş ve aile dengesini sağlaması ve analık haklarını kullanması açısından koruyucu

\footnotetext{
${ }^{3}$ Kanun Tarih ve Sayısı: 13.12.1966 / 811, Resmi Gazete Yayım Tarihi ve Sayısı: 22.12.1966 / 12484.
} 
hüküm getirmektedir. 37. madde, kadınların erkekler ile aynı işler için aynı haklara sahip olmalarının ve aile sorumluluklarını engellemeyecek şekilde çalışma koşullarına sahip olmaları gereğinin altını çizmektedir. Aynı haklar, babanın bebeğe bakması gereken durumlarda (annenin ölümü, ağır rahatsızlığı gibi) baba için de geçerlidir (European Commission, 2013).

İşyerlerinde kreş ya da emzirme odası gibi bir uygulama zorunluluğu olmadığı gibi bu konuda yapılan bir araştırmada, İtalya'da işverenler kanunların yeterliliği, maliyetli olması ve devletin desteğinin olmaması öncelikli sebepleri ile bu odaları kurmaya gönüllü olmadıkları ama çocuk bakımına önem verdikleri için gerek kısmi çalışma gerekse esnek çalışma saatleri uygulamaları ile aile sorumluluklarına verdikleri önemi dile getirmişlerdir (Broughton, 2013).

Türkiye: Türkiye, bu sözleşmeyi onaylamamıştır. Ancak mevcut mevzuatın analık halinde kadını ekonomik olarak koruyucu, işten çıkarılmasını önleyici hükümleri bulunmaktadır. Sözleşmenin 8. maddesi, ebeveyn sorumluluklarının işten çıkarılma sebebi olmaması gerektiğini belirtmektedir. Bu konuda 4857 sayılı İş Kanunu'nun 5. ve 18. maddeleri fesih durumuna karşı analık haklarını gözetmekte ve ayrımcı bir uygulama yapılmasının önüne geçmektedir.

Gebe veya emziren kadınların çalıştırılma şartlarıyla emzirme odaları ve çocuk bakım yurtlarına dair yönetmeliğine göre yaşları ve medeni halleri ne olursa olsun, 100-150 kadın işçi çalıştırılan işyerlerinde, bir yaşından küçük çocukların bırakılması, bakılması ve emziren işçilerin çocuklarını emzirmeleri için işveren tarafından çalışma yerlerinden ayrı ve işyerine en çok 250 metre uzaklıkta bir emzirme odasının kurulması zorunludur. Bu zorunluluğun yanı sıra 150 den çok kadın işçi çalıştırılan işyerlerinde, 0-6 yaşındaki çocukların bırakılması ve bakılması, emziren işçilerin çocuklarını emzirmeleri için işveren tarafindan, çalışma yerlerinden ayrı ve işyerine yakın bir yurdun kurulması da zorunluluk olarak gösterilmektedir. Yurt açma yükümlülüğünde olan işverenler yurt içinde anaokulu da açmak zorundadırlar ve yurt, işyerine 250 metreden daha uzaksa işveren taşıt sağlamakla yükümlüdür (Evren, 2012). 156 sayılı UÇÖ sözleşmesi, çocuk bakım üniteleri veya emzirme odaları hususunda herhangi bir sınırlama ve şart getirmemiştir ancak sözleşmenin 5. maddesi, aile sorumluluğu olan kişilerin mağdur olmalarını engellemek adına ihtiyaçlarının gözetilmesi gerektiğinin altını çizmektedir.

\section{4. $\quad 183$ Sayılı Sözleșme}

İtalya: $\mathrm{Bu}$ sözleşme İtalyan hükümeti tarafından kabul edilmiştir. Gebelik ve analık durumlarında İtalya'da çalışan kadınlar özel olarak korunmaktadırlar (Il Codice Civile, Articolo 2110). Kabul ettiği bu sözleşmeye istinaden 1204 sayılı Çalışan Anneleri Koruma Kanunu, gebe kadına doğum öncesi 2 ay, doğum sonrası 3 ay olmak üzere toplam 5 aylık (ortalama 20 hafta) izin vermektedir. Ancak kadının hem INPS'ye hem işverenine gerekli belgeleri vermesi gerekmektedir. Gebelik esnasında gerekli doktor kontrolleri için çalışan kadının izinleri de mevcuttur. Bu takdirde 5 ay boyunca alacağı ödeme son ücretinin \%80'ini kadar olacaktır (Laicita). Bunun dışında çocuk 8 yaşına gelene kadar 6 aylık izin hakkı daha bulunmaktadır. Özellikle çocuk üç yaşına gelene kadar alacağı 3 aylık izinde son ücretinin \%30'u kadar bir ödeme yapılmaktadır (EURES). Ayrıca, kadın çalışan hamileliğin başlangıcından, doğumdan sonraki bir sene geçinceye kadar işten çıkarılamamaktadır (Matteis and Accardo, 2011).

Türkiye: 183 sayılı sözleşme Türkiye tarafindan onaylanmamıştır ancak mevcut mevzuatta analık halinde çalışma, doğum izni ve emzirme izni düzenlenmiştir. 4857 sayılı kanunun 74. maddesi, kadın işçilerin doğumdan önce sekiz ve doğumdan sonra sekiz hafta olmak üzere toplam on altı haftalık süre için çalıştırılmamalarını şart koşmaktadır. Çoğul gebelik halinde 
doğumdan önceki süreye iki hafta eklenmektedir. Aynı madde, hamilelik süresince kadın işçiye periyodik kontroller için ücretli izin verilmesini ve kadının isteği halinde altı aya kadar ücretsiz izin verilmesini sağlamaktadır.

5510 sayılı Sosyal Sigortalar Genel Sağlı Sigortası yasasının 15. maddesine göre de Türkiye'de kadınlar doğumdan önce 8 , doğumdan sonra 8 hafta olmak üzere toplam 16 haftalık doğum izninden faydalanmaktadırlar. Bu izin, çoğul gebeliklerde 10'ar haftaya çıkarılmaktadır. Dolayısıyla bu maddeler 183 sayılı sözleşmenin kadınlara doğum nedeniyle verilmesi gereken iznin 14 haftadan az olamayacağı hususu ile uyum sağlamaktadır. Ayrıca 4857 sayılı kanunun 74. maddesi, bebeği 1 yaşına gelene kadar annenin günde 1,5 saati geçmeyecek şekilde emzirme izni de bulunmaktadır. Kadının analık halinde izin süresince sigortalılık halinin devamı ve günlük net kazancını geçmeyecek şekilde günlük kazancının üçte ikisi oranında verilecek geçici iş göremezlik ödeneği de yönetmelikte bulunmaktadır (Akpınar, 2013). Bu üçte iki oranı, 183 sayılı sözleşmenin de getirdiği bir standarttır.

\section{Sonuç}

Toplam nüfus içindeki kadın nüfus oranları açısından hemen hemen aynı orana sahip olan İtalya ve Türkiye kadınların işgücündeki hakları ve çalışma şartları bakımından farklılıklar içermektedir.

İşgücündeki kadınların korunmalarına yönelik ILO tarafından önerilen 4 adet sözleşme bulunmaktadır. 100, 111, 156 ve 183 no'lu bu sözleşmeler kadınların işgücüne katılmaları, ücretleri ve analık ile gebelik haklarına yönelik koruyucu düzenlemeler içermektedir. $100 \mathrm{ve}$ 111 no'lu sözleşmeler hem İtalya, hem Türkiye tarafından kabul edilmiş olup her iki ülkenin de kanunları sözleşmelerin içeriğine uygun düzenlemeler içermektedir. Ancak, istatistiklerde özellikle Türkiye'de kadınların işgücüne katılımları \%30, istihdam oranları \%27 seviyelerinde bulunmakta, hem de ücretler açısından erkeklerden daha az ücret almaktadırlar. İtalya'da ise kadın işgücü katılım oranı $\% 54$, istihdam oranı $\% 47$ olarak görülmektedir. Ücretler konusunda ise İtalya, AB 27 ülkesi içinde ortalamanın üstünde ücretlerle dikkat çekerken kadın ücretlerinin erkeklerin aldıkları ücretlerden daha düşük seviyede olduğu tespit edilmiştir. Dolayısıyla işgücüne katılmada ve istihdam edilmede eşitlik ilkesini savunan ve ILO sözleşmesini kabul eden Türkiye, istatistiklerde \%30 kadın işgücü katılım oranı ile sözleşme içeriğine tezat bir yapı içerisindedir. Zira 2013 yılında Türkiye genelinde \%48,30 olan işgücü katılım oranına bakıldığından erkek işgücü katılım oranının kadın işgücü katılım oranına göre oldukça yüksek olduğu görülmektedir. Ücretler konusunda da her iki ülke 111 no'lu eşit ücret sözleşmesini kabul etmiş olmasına rağmen kadın-erkek ücret eşitliğinin olmadığı istatistiklerde açıkça bellidir.

$\mathrm{Bu}$ hususta işgücündeki kadınların eğitim seviyelerine dikkat etmek gerekmektedir. Türkiye'de işgücündeki kadınların çoğu ilkokul seviyesinde iken İtalya'da lise düzeyinde olması önemli bir farkı daha ortaya çıkarmaktadır. Türkiye'de işgücüne katılan kadınların vasıfsız işlerde, mavi yakalı olarak çalıştıkları veya iş aradıkları, İtalya' da ise vasıf gerektiren işlerde çalıştıkları görülmektedir.

Kadınları iş hayatında koruyucu mahiyette olan 156 ve 183 no'lu sözleşmeler ise Türkiye tarafından kabul edilmemiş olmasına rağmen kanunlar sözleşmelerin içeriğine uygun düzenlemeler içermektedir. İtalya ise bu iki sözleşmeden sadece 183 no'lu sözleşmeyi onaylamıştır. Ancak yasalar tatmin edici, kadınların iş ve aile yaşamı arasındaki dengeyi korumasına yönelik esnek istihdama elverişli olarak şekillenmiştir. 
Sonuç olarak, benzer kadın nüfusuna sahip olduğu için kıyaslanan bu iki ülkeden Türkiye'de kadınların eğitim seviyeleri güçlendirilerek, devlet, belediyeler ve sivil toplum kuruluşları ile ortaklaşa seminer, kurs ve benzeri eğitim faaliyetleriyle hem eğitimli kadın işgücünün artması, hem de işgücüne katılıma teşvik edici protokollerin uygulanması gereklidir. Ücretlerin, AB 27 ülke ortalamasına ulaşması, hem kadın hem erkek işgücü katılım oranını da olumlu yönde etkileyecektir. Bu konuda asgari ücret düzeyinin yükseltilmesinin, saatlik medyan ücretin de artmasına sebep olacağı açıktır.

İtalya'da ise çoğunlukla toplu iş sözleşmeleriyle belirlenen ücretlerde kadınların aldıkları ücretlerin erkeklerin aldıkları ücretlere denk olması için sendikaların önlem almaları yerinde olacaktır.

Önemli olan ILO sözleşmelerini imzalamak ve kanunları sözleşme içeriklerine uygun şekilde düzenlemekle sınırlı kalınmaması, eyleme ne ölçüde geçtiğinin kontrollerinin yapılması ve eksik kalan durumlarda gerekli önlemlerin alınmasıdır.

\section{Kaynakça}

Akpınar, Teoman (2013), İş Sağlığı ve Güvenliği, Ekin Basım Yayın Dağıtım, Bursa, 426427.

Broughton, Andrea (2013), "EU Employers Take Family-Friendly Working Seriously", European Foundation for the Improvement of Living and Working Conditions, Dublin, 6,10

Burri, Susanne ve Hanneke van Eijken (2014), Gender Equality Law in 33 European Countries: How are EU rules transposed into national law?, European Commission, 127

Demiral, Cavit (2005), “4857 Sayılı İş Kanununda Cinsiyet Ayrımcılı̆̆ı Yasası”. Retrieved from

http://www.eakademi.org/incele.asp?konu=4857\%20SAYILI\%20\%DD\%DE\%20KANUNUN DA\%20C\%DDNS\%DDYET\%20AYRIMCILI\%D0I\%20YASA\%D0I\&kimlik=1110268879 \&url=makaleler/cdemiral-1.htm, 13.08.2013

Council of the European Union (2010), "The Gender Pay Gap in the Member States of the European Union: Quantitative and Qualitative Indicators", Belgian Presidency Report, Brussels, p.100

EURES, The European Job Mobility Portal, Living and Working Conditions, Italy. Retrieved from

https://ec.europa.eu/eures/main.jsp?catId=8440\&acro=living\&lang=en\&parentId=7783\&coun tryId=IT\&living $=16.04 .2014$

European Commission (2013), Your Social Security Rights In Italy, 13

Evren, Öcal Kemal (2012), İş Mevzuatı Açısından İşverenin El Kitabı, Seçkin Yayıncılık, Ankara, p.174.

Il Codice Civile Italiano, Libro Quinto Del Lavaro, Articolo 2110. Retrieved from http://www.jus.unitn.it/cardozo/Obiter Dictum/codciv/Lib5.htm, 16.04.2014

Gisella De Simone, Anna Rivara (2006), Report On Equal Pay, European Commission, 51

ILO, Convention 111. Retrieved from http://www.ilo.org/public/turkish/region/eurpro/ 30.09 .2013 
ILO, Convention 156. Retrieved from

http://www.ilo.org/dyn/normlex/en/f?p=NORMLEXPUB:12100:0::NO:12100:P12100_INST

RUMENT_ID:312301:NO, 02.01.2015.

ILO, Convention 183. Retrieved from

http://www.ilo.org/dyn/normlex/en/f?p=1000:12100:0::NO::P12100_ILO_CODE:C183, 02.02.2015.

ILO (2012), Decent Work Indicators Concepts and Definitions, Geneva, 98.

ILO Manual (2012), Decent Work Indicators Concepts and Definitions, ILO, Geneva, 133

Laicita, Radar, On This Day: 1204 Passed The Law For The Protection of Working Mothers. Retrieved from http://apocalisselaica.net/en/radar-laicita/iniziativa-laica/accadde-oggi-varatala-legge-1204-per-la-tutela-delle-lavoratrici-madri, 17.04.2014

Matteis, Aldo de, Paola Accardo ve Giovanni Mammone (2011), National Labour Law Profile, Italy, ILO. Retrieved from http://www.ilo.org/ifpdial/information-resources/nationallabour-law-profiles/WCMS 158903/lang--en/index.htm, 16.04.2014

Senato Della Repubblica, Constitution of the Italian Republic, Roma, 12

Summaries of EU Legislation. Retrieved from

http://europa.eu/legislation_summaries/glossary/equal_opportunities_en.htm, 28.04.2014

\section{Extended Abstract}

Working conditions for women are more difficult than men due to their family life responsibilities. ILO, in this regard, underlines the gender equality in woking life with various conventions. These conventions are; C100 Equal Remuneration Convention, C111 Discrimination ( Employment and Occupation) Convention, C156 Workers With Family Responsibilities Convention and C183 Maternity Protection Convention.

In this study, according to these contracts, the legal structure of Turkey and Italy are discussed. First of all, Turkish and Italian female population and laborforce datas were obtained and these datas were investigated in compliance with these countries legislations.

According to the statistics, the share of female population in the total population in Italy is $51.48 \%$ and $49.79 \%$ in Turkey. On the other hand, labor force participation rate for 15-64 age women is $54.10 \%$ for Italy and $30.80 \%$ for Turkey. Similarly, results show the superiority of the Italian women in the employment rate. While this ratio is $47 \%$ in Italy, in Turkey it is 27,10\%. Regards to EUROSTAT earnings datas, Italian women earn 11,46 Euro per hour in average in 2010 but unfortunately Turkish women earn 2,10 Euro per hour in average.

After statistics, contents of ILO conventions were investigated. Convention 100 and Convention 111 have been accepted by both Italian and Turkish governments. There are appropriate legal adjustments and laws to the content of these conventions for both countries. But, datas show that there ise a contrast between legal adjustments and statistics for Turkey with $30 \%$ of women in the labor force participation rate. Similarly, there is a contrast between Convention 111 and women wages. Altough both countries accept this convention, earnings are not as equal to men employees.

Convention 156 and Convention 183 are not accepted by Turkey. But, laws and legislations are so convenient to the contents of these two conventions. Laws are suitable for flexible employment and give opportunity to balance between the work and family life. 
As a result, the educational level of women in Turkey should be improved by the support of municipalities and non-governmental organizations with courses or training activities. Increasing of women wages to at least EU 27 average will affect labor force participation rate of women positively. In Italy, wages are determined by collective bargaining. So, trade unions should take action in this case.

The important thing is not only approving ILO conventions, but also making controls regularly and taking the necessary precautions. 